\title{
Kecukupan zat gizi makro, status gizi, stres, dan siklus menstruasi pada remaja ${ }^{1}$
}

Sufficient of macronutrients, nutritional status, stress and menstrual cycle on adolescent

\author{
Laras Sitoayu², Dewi Ayu Pertiwi², Erry Yudhya Mulyani
}

${ }^{2}$ Program Studi Ilmu Gizi, Fakultas Ilmu-Ilmu Kesehatan, Universitas Esa Unggul

\begin{abstract}
Background: Adolescence is transition period from children to adults which is characterized by the occurrence of changes in the body that allowed it to reproductive health problems. One of reproductive health problems is menstrual cycle disorders. Menstrual cycle disorder due to several factors including food intake, nutritional status and stress. Objective: This research supposed to know the association the sufficient of macro-nutrients, nutritional status and stress with menstrual cycle on adolescent at SMA Negeri Jakarta 21, 2016. Method: This design research is observation analytic with cross sectional approach. Sampling technique used proportionate random sampling and obtained 83 respondents adolescent. The technique of data collection used menstrual cycle questionnaire, DASS 14, food recall $3 \times 24$ hours (2 weekdays and 1 weekend), standardized food ingredient photos, nutrisurvey and SPSS. Results: There is $68.7 \%$ of respondents have an abnormal menstrual cycle. Based on statistical analysis of Chi-Square test, there is a significant relation between sufficient intake of carbohydrates ( $p=0.030)$, sufficient intake of protein $(p=0.001)$, sufficient intake of fat $(p=0.003)$, nutritional status $(p=0,004)$, stress $(p=0.000)$ and menstrual cycle. Based on logistic regression test results obtained the factors that most influence the menstrual cycle i.e. nutritional status (OR=20.16). Conclusion: Sufficient intake of macronutrients, nutritional status, and stress can affect menstrual cycle on adolescent, and nutritional status is the dominant factor that can affect the menstrual cycle.
\end{abstract}

KEY WORDS: macronutrients; menstrual cycle; nutritional status; stress

\begin{abstract}
ABSTRAK
Latar belakang: Masa remaja (adolescence) merupakan masa transisi dari masa anak-anak menuju dewasa yang ditandai dengan terjadinya perubahan di dalam tubuh yang memungkinkan terjadinya masalah reproduksi, salah satu masalahnya adalah gangguan siklus menstruasi. Gangguan siklus menstruasi disebabkan oleh beberapa faktor antara lain asupan makanan, status gizi, dan stres. Tujuan: Mengetahui hubungan antara kecukupan asupan zat gizi makro, status gizi, dan stres dengan siklus menstruasi pada remaja SMA Negeri 21 Jakarta tahun 2016. Metode: Desain penelitian adalah observasi analitik dengan pendekatan cross sectional. Teknik pengambilan sampling yang digunakan adalah proportionate random sampling dan diperoleh 83 responden remaja. Teknik pengumpulan data menggunakan kuesioner siklus menstruasi, DASS 14, food recall 3x24 jam, alat bantu foto bahan makanan terstandar, dan nutrisurvey. Hasil: Terdapat $68,7 \%$ responden mengalami siklus menstruasi tidak normal. Berdasarkan uji statistik Chi-Square menunjukkan ada hubungan yang signifikan antara kecukupan asupan karbohidrat ( $\mathrm{p}=0,030)$; kecukupan asupan protein $(\mathrm{p}=0,001)$; kecukupan asupan lemak $(\mathrm{p}=0,003)$; status gizi $(\mathrm{p}=0,004)$; dan stres $(\mathrm{p}=0,000)$ dengan siklus menstruasi pada remaja. Berdasarkan hasil uji regresi logistik didapatkan faktor yang paling berpengaruh terhadap siklus menstruasi yaitu status gizi $(\mathrm{OR}=20,16)$. Simpulan: Kecukupan asupan zat gizi makro, status gizi, dan stres mempengaruhi siklus menstruasi pada remaja dan status gizi merupakan faktor dominan yang dapat mempengaruhi siklus menstruasi.
\end{abstract}

KATA KUNCI: zat gizi makro; siklus menstruasi; status gizi; stres

\footnotetext{
' Dipresentasikan pada $7^{\text {th }}$ International Symposium on Wellness, Healthy Lifestyle and Nutrition pada tanggal 3-4 November 2016 di Yogyakarta kerjasama dengan Universiti Sains Malaysia, Malaysia dan Prince of Songkla University, Thailand

Korespondensi: Dewi Ayu Pertiwi, Program Studi Ilmu Gizi, Fakultas Ilmu-Ilmu Kesehatan, Universitas Esa Unggul, Jl.Arjuna Utara No.9, Kebon Jeruk, Jakarta 11510, Indonesia,e-mail: dewhy_pertiwi@yahoo.com
} 


\section{PENDAHULUAN}

Masa remaja (adolescence) merupakan masa transisi dari masa anak-anak menuju dewasa yang ditandai dengan terjadinya perubahan-perubahan di dalam tubuh yang memungkinkan untuk bereproduksi (1). Penduduk remaja di Indonesia sudah mencapai 64 juta $(27,6 \%)$ dari total penduduk Indonesia (2). Berdasarkan Pusat Data dan Informasi Kementerian Kesehatan RI, hanya 15,3\% remaja putri yang mengerti tentang masalah gangguan menstruasi (2). Salah satu masalah kesehatan reproduksi pada remaja adalah gangguan siklus menstruasi (3).

Siklus menstruasi merupakan waktu sejak hari pertama menstruasi sampai datangnya mensturasi periode berikutnya. Siklus menstruasi terjadi selama 28 hari. Rata-rata siklus menstruasi normal terjadi sekitar 21-35 hari sedangkan yang temasuk gangguan siklus menstruasi meliputi polimenorrhea ( $<20$ hari), oligomenorrhea $(>35$ hari), dan amenorrhea ( $>3$ bulan) (4). Siklus menstruasi normal bergantung pada tindakan dan interaksi hormon yang dilepaskan dari hipotalamus-hipofisis-ovarium dan efeknya pada endometrium (5). Pemendekan siklus menstruasi yang menyebabkan siklus menstruasi lebih singkat (polimenore) berhubungan dengan penurunan kesuburan dan keguguran sedangkan pemanjangan siklus menstruasi (oligomenore) berhubungan dengan kejadian anovulasi, infertilisasi, dan keguguran (6).

Dampak jika gangguan siklus menstruasi tidak ditangani akan mengakibatkan tubuh kehilangan terlalu banyak darah sehingga terjadi anemia (7). Perbedaan siklus menstruasi disebabkan oleh beberapa faktor, antara lain status gizi, asupan makanan, umur, aktivitas fisik, penyakit reproduksi, pengaruh rokok, dan stres (3). Penelitian yang dilakukan pada remaja putri Turki ditemukan 31,2\% mengalami ketidakteraturan pola menstruasi (8). Penelitian lain yang dilakukan pada remaja di India melaporkan sebanyak 22,1\% remaja mengalami ketidakteraturan pola menstruasi (9).

Kebutuhan gizi berhubungan erat dengan masa pertumbuhan, jika asupan gizi terpenuhi maka pertumbuhan akan optimal. Kebutuhan gizi yang harus terpenuhi berasal dari karbohidrat, lemak, dan protein. Asupan gizi yang tidak adekuat dapat menyebabkan kecukupan asupan zat gizi tidak baik sehingga dapat mempengaruhi ketidakteraturan menstruasi pada kebanyakan remaja (1). Asupan karbohidrat berhubungan dengan kalori selama fase luteal, asupan protein berhubungan dengan panjang fase folikular sedangkan asupan lemak berhubungan dengan hormon reproduksi (10).

Status gizi merupakan keadaan tubuh sebagai akibat konsumsi makanan dan penggunaan gizi. Selama ini telah diketahui bahwa wanita dengan status gizi kurang maupun lebih berisiko terjadinya gangguan siklus menstruasi. Penelitian yang dilakukan di PSIK FK UNSRAT Manado, menunjukan responden dengan status gizi kurus mengalami menstruasi tidak teratur sebanyak $66,7 \%$ sedangkan pada status gizi gemuk menstruasi tidak teratur sebanyak $81,8 \%$ (11).

Stres dapat mempengaruhi kesehatan bahkan dapat mempengaruhi siklus menstruasi, beberapa hasil studi menyatakan bahwa pelajar perawat di Kusyu University sebanyak 34\% mengalami menstruasi tidak teratur akibat stres dan wanita pertama sekali dipenjara dilaporkan sebanyak 30\% mengalami menstruasi tidak teratur akibat stres (12). Hasil studi pendahuluan yang dilakukan di bulan April 2016 pada 89 responden di SMA Negeri 21 Jakarta Timur, menyatakan sebanyak $60,8 \%$ remaja mengalami gangguan siklus menstruasi. Oleh karena itu, ditetapkan tujuan penelitian ini adalah mengetahui hubungan antara kecukupan asupan zat gizi makro, status gizi, dan stres dengan siklus menstruasi pada remaja SMA Negeri 21 Jakarta tahun 2016.

\section{BAHAN DAN METODE}

Desain penelitian adalah observasional analitik dengan metode cross sectional yang dilakukan pada bulan Maret-Juli 2016. Populasi yang diambil adalah remaja putri di SMA Negeri 21 Jakarta kelas X dan XI dengan jumlah populasi sebesar 319 orang. Teknik pengambilan sampel dengan proportionate random sampling sehingga diperoleh sampel sebesar 90 orang. Agar proporsi masingmasing kelas terwakili, maka prosedur pengambilan sampel dilakukan dengan cara lottery technique. Setelah penelitian dilakukan terdapat beberapa orang sampel yang tidak hadir dalam penelitian sehingga diperoleh 83 orang sampel. Setiap responden mengisi inform consent yang menyatakan bersedia menjadi sampel penelitian. Masing- 
masing sampel memenuhi kriteria inklusi yaitu siswi kelas $\mathrm{X}$ dan XI, telah menstruasi minimal 2 tahun dari masa menarche, bersedia menjadi responden, dan hadir pada saat pengambilan data. Kriteria eksklusi pada penelitian ini adalah siswi yang memiliki riwayat penyakit kronis, penyakit reproduksi, dan tidak merokok.

Variabel yang diteliti meliputi siklus menstruasi, kecukupan zat gizi makro, status gizi, dan stres. Pengumpulan data kecukupan asupan zat gizi makro (karbohidrat, protein, dan lemak) dilakukan dengan cara wawancara menggunakan kuisioner food recall 3x24 jam (1 hari libur dan 2 hari biasa) dengan bantuan foto bahan makanan terstandar dan nutrisurvey. Data asupan yang telah didapat kemudian dirata-rata dan dibandingkan dengan angka kecukupan gizi (AKG) sesuai umur setiap responden. Kecukupan asupan zat gizi makro dikategorikan baik apabila memenuhi 80-110\% dari AKG dan tidak baik apabila $<80 \%$ atau $>110 \%$ dari AKG.

Data antropometri diperoleh dengan cara pengukuran berat badan menggunakan timbangan injak Tanita dengan kapasitas $136 \mathrm{~kg}$ dan tingkat keakuratan $0,1 \mathrm{~kg}$ sementara pengukuran tinggi badan menggunakan microtoise dengan kapasitas $200 \mathrm{~cm}$ dan keakuratan $0,1 \mathrm{~cm}$. Pengukuran tinggi dan berat badan dilakukan 2 kali untuk mencegah bias dan ketidaktelitian. Status gizi responden ditentukan berdasarkan indeks massa tubuh berdasarkan umur (IMT/U). Data status gizi yang diperoleh dikategorikan normal apabila $z$-score -2SD sampai $1 \mathrm{SD}$ dan tidak normal apabila $z$-score $\leq-3 \mathrm{SD}$ sampai $<-2$ SD atau $\geq 1$ SD sampai 2 SD. Cara penilaian stres diukur dengan menggunakan depression anxiety stress scale (DASS) yang telah dimodifikasi menjadi 14 poin dan dikategorikan tidak stres apabila skor 0-14 poin sedangkan kategori stres apabila skor $>14$ poin. Data siklus menstruasi diperoleh dari waktu sejak hari pertama menstruasi sampai datangnya menstruasi periode berikutnya. Siklus menstruasi dicatat pada kuesioner menstruasi dilihat berdasarkan 3 bulan terakhir yaitu bulan Maret, April, dan Mei. Setiap responden mengisi tanggal menstruasi saat ini sampai tanggal selesainya menstruasi periode berikutnya hingga diperoleh data 2 siklus menstruasi responden. Siklus menstruasi dikategorikan normal apabila 21-35 hari dan tidak normal apabila $<21$ hari atau $>35$ hari.
Analisis data menggunakan uji Chi-Square $(\mathrm{p}<0,05)$ untuk menentukan hubungan dari variabel independen dan dependen. Regresi logistik digunakan untuk menentukan variabel yang paling berpengaruh terhadap variabel dependen.

\section{HASIL}

Hasil penelitian menunjukkan bahwa hubungan kecukupan asupan zat gizi makro dengan siklus menstruasi memiliki nilai $\mathrm{p}$-value 0,030 dan prevalence ratio 3,78 (karbohidrat); p-value 0,001 dan prevalence ratio 5,42 (protein); $p$-value 0,003 dan prevalence ratio 4,88 (lemak). Kecukupan asupan karbohidrat tidak baik memiliki persentase tertinggi yaitu $83,2 \%$ dan sebanyak $61,5 \%$ responden dengan asupan kecukupan karbohidrat tidak baik memiliki siklus menstruasi tidak normal. Kecukupan asupan protein tidak baik memiliki persentase tertinggi yaitu $65 \%$. Sebagian besar responden dengan kecukupan asupan protein tidak baik mengalami siklus menstruasi tidak normal dengan persentase 53\%. Sementara pada kecukupan asupan lemak, presentase tertinggi terdapat pada asupan lemak tidak baik yaitu $56,6 \%$ dan rata-rata responden dengan asupan lemak tidak baik mengalami siklus menstruasi tidak normal yaitu 47\% (Tabel 1).

Hubungan status gizi dengan siklus menstruasi memiliki nilai p-value 0,004 dan prevalence ratio 14,59. Sebagian besar responden $(73,5 \%)$ memiliki status gizi normal dan $22 \%$ responden mengalami status gizi lebih. Siklus menstruasi tidak normal memiliki persentase yang tinggi pada status gizi normal $(43,4 \%)$ dan pada status gizi lebih (25,3\%). Hubungan stres dengan siklus menstruasi memiliki nilai $p$-value 0,000 dan prevalence ratio 7,27 . Sebanyak $71,1 \%$ responden mengalami stres dan $57,8 \%$ responden yang mengalami stres memiliki siklus menstruasi yang tidak normal. Pada Tabel 2 didapatkan status gizi memiliki ratio pravalence tertinggi yaitu 20,157 diikuti dengan stres dan kecukupan asupan lemak yaitu 9,298 dan 4,082.

\section{BAHASAN}

Berdasarkan hasil penelitian yang dilakukan, kecukupan asupan karbohidrat berhubungan dengan siklus menstruasi. Responden dengan kecukupan asupan 
Tabel 1. Analisis bivariat hubungan kecukupan zat gizi makro, status gizi, dan stres dengan siklus menstruasi

\begin{tabular}{|c|c|c|c|c|c|c|c|c|c|}
\hline \multirow{3}{*}{ Kategori } & \multicolumn{4}{|c|}{ Siklus menstruasi } & \multirow{2}{*}{\multicolumn{2}{|c|}{ Total }} & \multirow{3}{*}{$\mathbf{p}$} & \multirow{3}{*}{$\begin{array}{l}\text { Prevalence } \\
\text { ratio }\end{array}$} & \multirow{3}{*}{$95 \% \mathrm{CI}$} \\
\hline & \multicolumn{2}{|c|}{ Normal } & \multicolumn{2}{|c|}{ Tidak normal } & & & & & \\
\hline & $\mathrm{n}$ & $\%$ & $\mathbf{n}$ & $\%$ & n & $\%$ & & & \\
\hline \multicolumn{10}{|c|}{ Kecukupan asupan karbohidrat } \\
\hline Baik & 8 & 9,6 & 6 & 7,2 & 14 & 16,8 & $0,030^{*}$ & 3,78 & $1,15-12,38$ \\
\hline Tidak baik & 18 & 21,7 & 51 & 61,5 & 69 & 83,2 & & & \\
\hline \multicolumn{10}{|c|}{ Kecukupan asupan protein } \\
\hline Baik & 16 & 19,3 & 13 & 15,7 & 39 & 35,0 & $0,001^{*}$ & 5,42 & $1,99-14,78$ \\
\hline Tidak baik & 10 & 12,0 & 44 & 53,0 & 54 & 65,0 & & & \\
\hline \multicolumn{10}{|c|}{ Kecukupan asupan lemak } \\
\hline Baik & 18 & 21,7 & 18 & 21,7 & 36 & 43,4 & $0,003^{*}$ & 4,88 & $1,79-13,29$ \\
\hline Tidak baik & 8 & 9,6 & 39 & 47,0 & 47 & 56,6 & & & \\
\hline \multicolumn{10}{|l|}{ Status gizi } \\
\hline Normal & 25 & 30,1 & 36 & 43,4 & 61 & 73,5 & $0,004^{*}$ & 14,59 & $1,84-115,57$ \\
\hline Lebih & 1 & 1,2 & 21 & 25,3 & 22 & 26,5 & & & \\
\hline \multicolumn{10}{|l|}{ Stres } \\
\hline Stres & 15 & 18,1 & 9 & 10,8 & 24 & 28,9 & $0,000^{*}$ & 7,27 & $2,53-20,88$ \\
\hline Tidak & 11 & 13,3 & 48 & 57,8 & 59 & 71,1 & & & \\
\hline
\end{tabular}

* signifikan dengan $\mathrm{p}<0,05$ (Chi-Square)

Tabel 2. Analisis multivariat hubungan kecukupan zat gizi makro, status gizi, dan stres dengan siklus menstruasi

\begin{tabular}{lcccc}
\hline \multicolumn{1}{c}{ Variabel } & Koefisien & p & Prevalence ratio & 95\%CI \\
\hline Kecukupan asupan lemak & 1,407 & $0,021^{*}$ & 4,082 & $1,232 \pm 13,528$ \\
Status gizi & 3,004 & $0,012^{*}$ & 20,157 & $1,962 \pm 207,106$ \\
Stres & 2,230 & $0,001^{*}$ & 9,298 & $2,572 \pm 33,617$ \\
\hline
\end{tabular}

*signifikan dengan $\mathrm{p}<0,05$ (analisis regresi logistik)

karbohidrat tidak baik berisiko 3,79 kali mengalami siklus menstruasi tidak normal dibandingkan dengan responden yang memiliki kecukupan asupan karbohidrat baik. Hasil penelitian ini sesuai dengan penelitian yang dilakukan pada remaja di Semarang, bahwa ada hubungan antara asupan karbohidrat dengan siklus menstruasi $(p=0,000$ dan $\mathrm{OR}=7,14)(13)$. Berdasarkan hasil food recall $3 \times 24$ jam rendahnya kecukupan asupan karbohidrat responden disebabkan karena pola makan responden yang tidak teratur yaitu sering meninggalkan waktu makan utama, mengkonsumsi susu pada saat makan pagi dibandingkan dengan mengonsumsi hidangan menu lengkap, sebagian responden menjalankan diet dan beberapa responden yang tidak mengkonsumsi nasi sebagai makanan utama.

Karbohidrat merupakan sumber peningkatan asupan kalori selama fase luteal sehingga apabila asupan karbohidrat terpenuhi maka tidak akan terjadi pemendekan fase luteal(10). Peningkatan asupan energi bersumber pada asupan karbohidrat dan diketahui bahwa terjadi peningkatan asupan karbohidrat yang signifikan selama fase premenstruasi (14).Ketika tingkat estrogen menurun dan terjadi hipoglikemia selama pramenstruasi, maka ada kebutuhan fisiologis untuk meningkatnya asupan karbohidrat selama fase luteal pada siklus menstruasi yang mempengaruhi perilaku makan yang sebenarnya atau keinginan untuk makan (food craving) (15). Konsentrasi glukosa darah yang rendah dapat mengakibatkan tubuh memproduksi hormon adrenalin. Adrenalin dapat menghentikan efektivitas progesteron yang berfungsi menekan aktivitas kerja hormon estrogen sehingga siklus menstruasi tidak menjadi lebih panjang (16).

Berdasarkan hasil penelitian diketahui adanya hubungan yang signifikan antara kecukupan asupan protein dengan siklus menstruasi, terdapat risiko sebesar 5,42 kali mengalami gangguan siklus menstruasi pada 
responden yang memiliki kecukupan asupan protein tidak baik. Kecukupan asupan protein rendah disebabkan oleh pola makan responden yang tidak teratur, sering mengonsumsi hidangan sepinggan yaitu hidangan tersebut mengandung sumber protein yang rendah. Berdasarkan hasil food recall 3x24 jam, konsumsi lauk hewani pada responden lebih tinggi dibandingkan dengan konsumsi lauk nabati. Lauk hewani yang paling sering dikonsumsi adalah daging ayam (32,9\%) dengan hidangan berupa ayam goreng (16,3\%). Asupan lauk nabati paling sering dikonsumsi adalah tempe $(3,9 \%)$ dengan hidangan yang paling sering dikonsumsi adalah tempe goreng (2,1\%).

Asupan protein hewani yang berlebih akan memperpanjang fase folikuler (10). Hasil penelitian yang dilakukan untuk mengetahui pengaruh konsumsi vegetarian terhadap hormon seks, didapatkan 9 orang vegetarian diberi konsumsi makanan yang mengandung daging mengalami pemanjangan fase folikuler ratarata 4,2 hari, peningkatan folicle stimulating hormone (FSH), dan penurunan estradiol (E2) secara signifikan. Sebaliknya, 16 orang dengan makanan biasa yang beralih ke makanan dengan konsumsi daging yang kurang selama dua bulan mengalami penurunan puncak luteinizing hormone (LH) dan pemendekan fase folikuler rata-rata 3,8 hari (10). Penelitian lain menjelaskan bahwa tingginya konsumsi protein hewani meningkatkan risiko terjadinya infertilitas akibat anovulasi dan konsumsi protein nabati dapat mengurangi risiko terjadinya infertilitas $(17,18)$.

Berdasarkan penelitian yang telah dilakukan diketahui bahwa kecukupan asupan lemak berhubungan dengan siklus menstruasi. Responden dengan kecukupan asupan lemak tidak baik berisiko 4,88 kali mengalami gangguan siklus menstruasi dibandingkan dengan responden yang memiliki kecukupan asupan lemak baik. Hasil penelitian ini sesuai dengan penelitian yang dilakukan pada remaja di Semarang, bahwa ada hubungan antara asupan lemak dengan siklus menstruasi $(p=0,000$, $\mathrm{OR}=6,10)(13)$. Menstruasi wanita akan tidak teratur apabila memiliki simpanan lemak kurang dari $20 \%$ dari total berat badan (19).

Berdasarkan hasil food recall 3x24 jam, sebagian besar responden mengkonsumsi hidangan yang digoreng (50,2\%) dan ditumis (49,7\%). Kandungan lemak trans pada makanan digoreng dapat mempengaruhi siklus menstruasi. Rendahnya asupan lemak trans dan lebih besarnya asupan lemak tidak jenuh berhubungan dengan menurunya gangguan siklus menstruasi sehingga kejadian infertilitas akan menurun (18). Penelitian lanjutan yang dilakukan pada wanita Jepang didapatkan bahwa terdapat hubungan positif antara asupan lemak tak jenuh tunggal dan konsentrasi serum estrogen, serta terdapat hubungan terbalik antara serat dan serum estrogen (20). Asupan lemak tak jenuh ganda secara signifikan mengurangi panjang siklus menstruasi, yaitu terdapat perbandingan yang terbalik antara asupan lemak tak jenuh ganda dengan panjang siklus. Rendahnya asupan lemak tak jenuh berisiko 2,12 kali mengalami panjangnya siklus menstruasi (21). Asupan rendah lemak akan menyebabkan tiga efek utama yaitu siklus menstruasi memanjang dan meningkat rata-rata 1,3 hari; lamanya waktu menstruasi meningkat rata-rata 0,5 hari; dan fase folikuler meningkat rata-rata 0,9 hari (10). Pola makan tinggi serat dan rendah lemak menyebabkan berat badan dan massa lemak rendah sedangkan asupan kalori yang rendah dan adanya gangguan makan menyebabkan terjadinya gangguan sekresi pengeluaran hormon gonadotropin dan hipofisis (20).

Akumulasi asupan karbohidrat, protein maupun lemak yang berlebihan akan diubah menjadi simpanan lemak. Tingginya simpanan lemak akan menyebabkan terjadinya gangguan siklus menstruasi dengan akumulasi kadar estrogen dalam tubuh sehingga apabila asupan karbohidrat, protein maupun lemak terpenuhi dan sesuai dengan kebutuhan maka siklus menstruasi akan normal (3). Hasil penelitian yang telah dilakukan diperoleh status gizi berhubungan dengan gangguan siklus menstruasi. Pada responden dengan status gizi tidak normal berisiko 14,58 kali mengalami siklus menstruasi tidak normal dibandingkan dengan responden yang memiliki status gizi normal. Penelitian lain sejalan dengan penelitian ini menunjukkan bahwa ada hubungan yang signifikan antara status gizi dengan siklus menstruasi pada remaja putri $(22,23)$. Setelah dilakukan uji regresi logistik didapatkan bahwa status gizi merupakan faktor yang paling dominan mempengaruhi siklus menstruasi $(\mathrm{OR}=20,157)$.

Penelitian lain dilakukan pada wanita India berusia 16-40 tahun menunjukkan bahwa perempuan dengan indeks massa tubuh (IMT) yang tidak normal memiliki 
risiko lebih tinggi terhadap kejadian gangguan siklus menstruasi dibandingkan dengan mereka dengan indeks massa tubuh normal (24).Penelitan lain yang dilakukan di Australia dan New Zealand didapatkan hasil bahwa siswa dengan obesitas (BMI $27 \mathrm{~kg} / \mathrm{m}^{2}$ ) secara signifikan memiliki risiko 69,3 kali lebih lebih tinggi mengalami oligomenorrhea dengan risiko 18,5 kali mengalami panjang durasi menstruasi lebih tinggi dari 7 hari (25). Risiko untuk amenorrhea dan oligomenorrhea meningkat dua kali lipat oleh setiap kenaikan unit kelas obesitas (26).

Gizi lebih pada remaja putri dapat menyebabkan gangguan menstruasi, hal ini disebabkan terjadinya peningkatan produksi estrogen yang diketahui bahwa selain ovarium jaringan adiposa juga dapat memproduksi estrogen. Peningkatan estrogen yang terus menerus secara tidak langsung menyebabkan peningkatkan hormon androgen yang dapat menggangu perkembangan folikel sehingga tidak dapat menghasilkan folikel yang matang (23). Kondisi kegemukan berkaitan dengan proses perubahan androgen menjadi estrogen. Makanan yang bergizi tinggi dan berlemak tinggi akan mengakibatkan pertambahan berat badan pada perempuan remaja. Kolesterol yang terdapat pada lemak tubuh yang berlebihan merupakan prekusor dari estrogen sehingga produksi estrogen cenderung berlebihan. Kadar estrogen dalam darah akan meningkatkan akibat kolesterol tinggi (3). Peningkatan cepat kadar estrogen menimbulkan umpan balik positif terhadap hipotalamus dan kelenjar hipofisis sehingga terjadi sentakan peninggian LH. LH yang terlalu cepat keluar menyebabkan hiperandrogenisme kadar testosterone yang rendah sehingga tidak terjadi ovulasi (3).

Remaja perempuan yang mempunyai status gizi kurus sekali akan mengalami hambatan dengan menstruasinya. Kehilangan berat badan secara besarbesaran dapat menyebabkan penurunan hormon gonadotropin untuk pengeluaran LH dan FSH yang mengakibatkan estrogen akan turun sehingga berdampak negatif pada siklus menstruasi. Sekresi LH yang terganggu akibat penurunan berat badan dapat menyebabkan pemendekan fase luteal (27). Kekurangan gizi dianggap salah satu yang penting faktor yang menyebabkan gangguan hipotalamus-hipofisis-ovarium (28). Remaja yang memiliki IMT kurang dari $17,5 \mathrm{~kg} / \mathrm{m}^{2}$ memiliki risiko 2,06 mengalami siklus menstruasi yang tidak teratur(29).

Berdasarkan penelitian yang telah dilakukan, stres berhubungan dengan gangguan siklus menstruasi. Pada responden yang mengalami stres terdapat risiko 7,27 kali gangguan siklus menstruasi dibandingkan dengan responden yang tidak mengalami stres. Hasil penelitian ini sejalan dengan penelitian sebelumnya yang menjelaskan ada hubungan yang signifikan antara stres dan gangguan menstruasi $(30,31)$. Siswi dengan stres tinggi memiliki risiko yang signifikan $(1,91$ kali) mengalami durasi menstruasi lebih dari 7 hari (25). Berdasarkan hasil wawancara, faktor penyebab stres terbanyak $(63,2 \%)$ pada responden disebabkan karena adanya school stress. Rasa takut terhadap menurunnya prestasi disekolah dan banyaknya tugas yang diberikan guru menjadi faktor utama penyebab stres pada responden. Selain itu, responden sedang dihadapkan dengan ujian kenaikan kelas yang menyebabkan tingkat stres pada responden semakin meningkat.

Stres seringkali membuat siklus mentruasi yang tidak teratur. Gangguan pada pola menstruasi melibatkan mekanisme regulasi intergratif yang mempengaruhi proses biokimia dan seluler seluruh tubuh termasuk otak dan psikologis. Pengaruh otak dalam reaksi hormonal terjadi melalui jalur hipotalamus-hipofisis-ovarium yang meliputi multi efek dan mekanisme kontrol umpan balik. Pada keadaan stres terjadi aktivasi pada amygdala pada sistem limbik. Sistem ini menstimulasi pelepasan hormon dari hipotalamus yaitu corticotropic releasing hormone (CRH). Hormon ini secara langsung akan menghambat sekresi GnRH hipotalamus pada tempat produksinya di nucleus arkuata. Proses ini kemungkinan terjadi melalui penambahan sekresi opiod endogen (32).

Peningkatan CRH akan menstimulasi pelepasan endorfin dan adino cortiticotropic hormone (ACTH) ke dalam darah. Endorfin sendiri merupakan opiod endogen yang peranannya terbukti mengurangi rasa nyeri. Peningkatan hormone ACTH menyebabkan peningkatan pada kadar kortisol darah. Pada wanita dengan gejala amenore hipotalamik menunjukkan keadaan hiperkortisolisme yang disebabkan adanya peningkatan CRH dan ACTH (32). Hormon-hormon tersebut secara 
langsung dan tidak langsung menyebabkan penurunan kadar GnRH, yaitu melalui jalan ini stres menyebabkan gangguan siklus menstruasi. Dari yang tadinya siklus menstruasinya normal menjadi oligomenorrhea, polimenorrhea, atau amenorrhea. Gejala klinis yang timbul ini tergantung pada derajat penekanan pada GnRH. Gejala-gejala ini umumnya bersifat sementara dan biasanya akan kembali normal apabila stres yang ada dapat diatasi(32).

\section{SIMPULAN DAN SARAN}

Kecukupan asupan zat gizi makro, status gizi, dan stres memiliki hubungan yang bermakna dengan siklus menstruasi pada remaja. Status gizi tidak normal pada remaja merupakan faktor dominan terjadinya gangguan siklus menstruasi $(\mathrm{OR}=20,157)$. Remaja dapat lebih memperhatikan asupan makanan yang sehat dan tidak melewatkan waktu makan utama sehingga memenuhi kebutuhan sehari yaitu $2.125 \mathrm{kkal}$ dan kecukupan asupan zat gizi makro dapat terpenuhi. Remaja diharapkan lebih memperhatikan pola makan dan jenis pilihan makanan sehingga mencapai berat badan ideal dan status gizi normal. Menghindari dan mengurangi faktor-faktor penyebab stres, serta diharapkan remaja mencatat tanggal menstruasi setiap bulannya agar dapat diketahui siklus menstruasi termasuk normal atau tidak normal.

\section{Pernyataan konflik kepentingan}

Penulis menyatakan tidak ada konflik kepentingan dengan pihak-pihak yang terkait dalam penelitian ini.

\section{RUJUKAN}

1. Dieny. Permasalahan gizi pada remaja putri. Yogyakarta: Graha Ilmu; 2014.

2. Kementrian Kesehatan RI. Infodatin pusat data dan informasi kesehatan RI situasi kesehatan reproduksi remaja. Jakarta: Pusat Data dan Informasi; 2013.

3. Wiknjosastro H. Ilmu kandungan. Jakarta: Yayasan Bina Pustaka Sarwono Prawirohardjo; 2006.

4. Indiarti MT. Kehamilan, persalinan dan perawatan bayi. Yogyakarta: Diglossia Media; 2007.

5. Deligeoroglou E, Tsimaris P, Deliveliotou A. Menstrual disorders during adolescence. Pediatr Endocrino 2009;3(1):150-9.
6. Gudmundsdottir SL, Flanders WD, Augestad LBA. Longitudinal study of physical activity and menstrual cycle characteristics in healthy norwegian women the nord-trøndelag health study. Norsk Epidemiologi 2011;20(2):163-71.

7. Mesarini BA, Astuti VW. Stres dan mekanisme koping terhadap gangguan siklus menstruasi pada remaja putri. Jurnal STIKES 2013;6(1):31-42.

8. Cakir M, Mungan I, Karakas T, Girisken L, Okten A. Menstrual pattern and common menstrual disorders among university students in Turkey. Pediatr Int 2007;49(6):93842.

9. Sanjay VW, Dharampal G, Jayesh YD. Age at marche and menstrual cycle pattern among school adolescent girls in central India. Global Journal of Health Sciene 2011;4(1):105-11.

10. Paath EF. Gizi dalam kesehatan reproduksi. Jakarta: EGC; 2005.

11. Felicia, Hutagaol E, Kundre R. Hubungan status gizi dengan siklus menstruasi pada remaja putri di PSIK FK UNSRAT Manado. Journal Keperawatan 2015;3(1):1-7.

12. Allsworth JE, Clarke, Peipert JF, Hebert R, Crnp AC, Boardman LA. The influence of stress on the menstrual cycle among newly incarcerated women. Womens Health Issues 2007;17(4):202-9.

13. Rachmawati PA. Hubungan asupan zat gizi, aktivitas fisik, dan presentase lemak tubuh dengan gangguan siklus menstruasi pada penari [Skripsi]. Semarang: Program Studi Ilmu Gizi Universitas Dipenogoro; 2014.

14. Cheikh, Al-hourani, Lightwoler. Energy and nutrient intakes during different phases of the menstrual cycle in females in the United Arab Emirates. J Ann Nutr Metab 2009;54:124-8.

15. Cohen IT, Sherwin BB, Fleming AS. Food cravings, mood, and the menstrual cycle. Horm Behav 1987;21(4):45770.

16. Mazarina D. Hubungan kebiasaan makan dengan kejadian sindrom pramenstruasi pada remaja putri. Jurnal Teknologi dan Kejuruan 2009;32(2):197-208.

17. Chavarro JE, Rich-Edwards JW, Rosner BA, Willett WC. Protein intake and ovulatory infertility. Am J Obstet Gynecol 2008;198(2):210.e1-7.

18. Chavarro JE, Rich-Edwards JW, Rosner BA, Willett WC. Diet and lifestyle in the prevention of ovulatory disorder infertility. Obstet Gynecol 2007;110(5):1050-8.

19. Dewantari NM. Peran gizi dalam kesehatan reproduksi. Jurnal Skala Husada 2013;10(2):219-24.

20. Nagata C, Takatsuka N, Kawakami N, Shimizu H. Total and monounsaturated fat intake and serum estrogen concentrations in premenopausal japanese women. Nutr Cancer 2000;38(1):37-9. 
21. Nagata C, Oba S, Shimizu H. Associations of menstrual cycle length with intake of soy, fat, and dietary fiber in Japanese women. Nutr Cancer 2006;54(2):166-70.

22. Dars S, Sayed K, Yousufzai Z. Relationship of menstrual irregularities to BMI and nutritional status in adolescent girls. Pak J Med Sci 2014;30(1):140-4.

23. Wei S, Schdmidt MD, Dwyer T, Norman RJ, Venn AJ. Obesity and menstrual irregularity: associations with SHBG, testosterone and insulin. Obesity 2009;17(5):1070-6.

24. Sheela J, Sunita G, Savita S, Sulbha J. Association of body mass index with menstrual cycle irregularities in women between 16 - 40 year age. PJMS 2014;4(1):59-61.

25. Chang PJ, Chen PC, Hsieh CJ, Chiu LT. Risk factors on the menstrual cycle of healthy Taiwanese college nursing students. Aust N Z J Obstet Gynaecol 2009;49(6):68994.

26. Castillo ML, Lopez AJ, Villa A, Gonzalez J. Menstrual cycle length disorders in 18-to 40-y-old obese women. Nutrition 2003;19(4):317-20.

27. Nikkmawati E. Analisis perilaku gizi remaja untuk pengembangan model pendidikan gizi yang berintegrasi dengan kegiatan sekolah. Bandung: Penelitian Fakultas
Pendidikan Teknologi dan Kejuruan Universitas Pendidikan Indonesia Bandung; 2009.

28. Fujiwara T. The discrepancy between BMI and selfrecognition of adequate body weight may cause insufficient food intake and habits in young women in Japan. Bull Ashiya Coll 2005;27:75-80.

29. Mari J, Rvlaid T. The effect of gynecologic age, body mass index and psychosocial environment on menstrual regularity among teenaged females. Acta Obstet Gynecol Scand 2005;84(7):645-9.

30. Ekpenyong CE, Davis KJ, Akpan UP, Daniel NE. Academic stress and menstrual disorders among female undergraduates in Uyo, South Eastern Nigeria - the need for health education. Niger J Physiol Sci 2013;26(2):193-8.

31. Roswendi A. Hubungan stres psikologis dengan siklus menstruasi pada siswi di SMA 5 Cimahi tahun 2011. Jurnal Keperawatan 2011;11(7):9.

32. Davis JM, Segars J. Menstruation and menstrual disorders: anovulation. Glob Libr Women's Med [series online] 2009 [cited Okt 2016]. Available from: URL: https://www.glowm. com/section_view/heading/Menstruation $\% 20$ and $\% 20$ Menstrual\%20Disorders:\%20Anovulation/item/295 